\title{
Updating the CS Curriculum: Traditional vs. Market-Driven Approaches
}

\author{
Nedzad Mehic \& Ali Al-Soufi \\ University of Bahrain, Isa Town, PO Box 32038, Bahrain \\ nedzad@batelco.com \& asoufi@batelco.com.bh
}

\begin{abstract}
The paper describes a method of updating a curriculum of a typical computer science department. The suggested approach promotes the role of a university as an academic environment, targeting excellence in teaching degree programs, as well as a qualified partner in partnership with businesses, especially with industry, in sharing knowledge and skills, supporting the concept of a quality process and quality products. Cooperation with industry firms, through real problem solving approaches and using emerging technologies that might drive the best demand in future markets, will prepare students to take advantage of opportunities, gain experience, and make an impact immediately. As a case study, the paper describes how this approach is applied to Computer Science Department at University of Bahrain.
\end{abstract}

Keywords: CS curriculum, Geographical Information Systems (GIS), Information Technology (IT)

\section{Introduction}

Today, the demand for skilled people who can create, apply and use Information Technology (IT) goes beyond tradition, cutting across manufacturing and services, transportation, health care, education and government (Mitchel, Carnes, \& Mendosa, 1994). IT offers many young people high-paying jobs with amazing opportunities for advancement in a career.

Recent studies show there are now 350,000 unfilled computer-related jobs in USA and that another 200,000 new jobs will be added to that number each year. These numbers are expected to grow by $70 \%$ over the next five years (O’Brien, 1998). In another study, conducted by Coopers and Lybrand (Trendsetter, 1996), nearly half the CEOs of America's fastest growing companies reported that they had inadequate numbers of information technology workers to staff their operations.

Shortage in the IT arena puts enormous pressure on col-

Material published as part of this journal, either on-line or in print, is copyrighted by the publisher of Informing Science. Permission to make digital or paper copy of part or all of these works for personal or classroom use is granted without fee provided that the copies are not made or distributed for profit or commercial advantage AND that copies 1) bear this notice in full and 2) give the full citation on the first page. It is permissible to abstract these works so long as credit is given. To copy in all other cases or to republish or to post on a server or to redistribute to lists requires specific permission and payment of a fee. Contact

Editor@gise.org to request redistribution permission. leges and universities to prepare students for future job markets and to expose them to a broad range of technologies and methods. Business today needs college and university graduates to make an impact immediately and become productive employees or to hit the ground running, almost immediately after joining the company (Musthaler, 1997). These institutions must provide students with the knowledge, problem-solving skills, and tools needed for a successful career start.

However, the number of students actually pursuing computer-related degrees in the USA is down dramatically compared to ten years ago. Recent studies also show significant increases in contract and temporary employment. Companies are trying to cut the costs by hiring skilled people on a temporary basis to handle the current problems, upgrades or expansions the business is facing. These temps include experienced university professors and university students, (Stanford Computer Industry Project Software, 1998). In contrast to the situation in the USA, the number of students registering every year in the Computer Science Department at University of Bahrain (UOB) is steadily rising. Every year more and more young people are trying to enter the College of Science and are choosing courses in the Computer Science Department. Once they graduate holding their B.Sc. and M. Sc. degrees in computer science, they have high expectations for challenging careers and high-profile positions in Bahrain or other GCC countries where market demand in IT skills is high. 


\section{Updating CS Curriculum}

With the full support from the government of Bahrain, the University, and College top officials, the Computer Science Department is trying to cope with this situation, updating curricula to serve the community better using all available human and other resources to prepare students for the future.

\section{CS Department at UOB}

The Computer Science Department at the University of Bahrain was established in 1988 following the merger of the Gulf Polytechnic and the Bahrain College for Art, Science, and Education. Prior to this date, the Electrical Engineering Department at the Gulf Polytechnic was offering a B.Sc. in computer science. The Computer Science Department is now part of the College of Science at the University of Bahrain and it offers B.Sc. degrees and, starting from September 1999, M. Sc. degrees in computer science. The Department now has an average of 600 students majoring in computer science. Each semester an average of 50 students graduate and they are seeking jobs in computer companies, government ministries, and in the education sector in Bahrain and in the Gulf area. They work as programmers, systems analysts, system administrators, DP managers as well as seeking to set up their own companies.

The Department has nine computer labs equipped with Pentium type PC's and a number of highly advanced UNIX workstations. All machines in all labs are linked to the departmental network and to the university wide network. Internet access is also provided to both academic staff and students.

\section{B. Sc. in Computer Science}

Recently the Department decided to update its old B.Sc. program in computer science, introduced in 1988. The new B.Sc. brought changes in the structure as well as in the course contents. When creating the new degree, the department paid special attention to a number of factors, including the following:

- Meeting the ACM/IEEE accreditation criteria for a computer science degree

- Establishing a balance between the amount of theory and practice in each course

- Satisfying present and future job market demands but also considering the needs of those students who are likely to do postgraduate studies in Bahrain or elsewhere. They should be provided with foundation knowledge, such as the fundamentals of system analysis, structured and object oriented programming, database concepts and telecommunications.

- Making courses, such as systems analysis and design, software engineering, computer networks, and database management systems compulsory instead of elective, as in the old curriculum

- Redefining the role of math courses in CS curriculum (Triangle Coalition, 1998).

Typically, there are different opinions among faculty in a computer science department regarding the structure of its CS curriculum. Our Department was faced with the problem of how to properly structure the curriculum to promote an understanding of global concepts, to find the proper role of theory in teaching and research, and to offer flexibility and adaptability to inevitable changes in a local and global IT environment.

It is obvious that changes are needed to update the way the traditional computer science is taught (Pierce, 1994). Future high demand for NT skills, voice over IP, ATM, high-speed access to the Internet, data networks, Lightweight Directory Access Protocol (LDAP), Microsoft Active Directory, Novell's Novell Directory Services (NDS) and so on will require special attention for every CS department (Tackett, 1998). Demand is expected to remain high for programmers, systems integrators, network and Internet experts and database designers well into the 21 st century. Some computer science departments still resist the changes and they may find difficulties in coping meeting the employers' needs because of their lack of experience, expertise and the lack of management skills.

One solution to the mentioned problems could be a market-driven curriculum that satisfies the needs of local businesses. Those who accepted this approach, pursue emerging technologies that might drive the best demand in the market place by offering popular courses such as Microsoft Visual Basic, Java, C++, Oracle, and the Internet concepts. This approach is not acceptable to traditionalists, who argue that technology cannot be the target of any program and students should be taught integrated systems rather than technology. The curriculum they support puts emphasis on fundamental concepts, fundamen- 
tals of system analysis, structured programming, database concepts and telecommunications, the role of theoretical studies, and analytical skills which are especially important for students continuing their studies towards M. Sc. and Ph.D. degrees. However, this approach might not provide students with vital skills and experience they need to find the job they really want.

We decided to accept the third solution, which tries to maintain high educational standards while exploiting the potentials of the technology (Schmidt \& Kirby, 1995). Our approach is based on solid fundamentals, broadbased fundamental IT/IS education, and active students' participation in problem-solving research. The success of our B. Sc. program will be measured by the number of graduates who can find the jobs they want and the way they can integrate in new environments. We are now carefully monitoring progress of our final year students who are taking a part in industrial training. So far the feedback from industry has been encouraging indicating their satisfaction with the performance and quality of our students.

Important components of our approach are closer links and active cooperation with local businesses and industry in particular that can refresh teaching computer science through knowledge transfer and acquisition. One must not forget the fact that education can reflect excellence only when instructors, as the motivators and catalysts of the learning process, are adequately prepared, highly motivated, appropriately recognized and rewarded (US Cooperative State Research, Education, and Extension Service, 1997).

\section{CS Department Strategy at UOB}

A student pursuing a B.Sc. degree in CS must complete a total of 131 credits divided into university, college, and department requirements, as well as the department major in computer science requirements. Students majoring in computer science have the choice of the following one of the two tracks:

a) Single -Track or pure B.Sc. in computer science

b) Major - Minor track.

In the Single-Track program, the student must complete 73 credit hours in the major courses, in addition to the standard B.Sc. foundation courses. In the Major-Minor track, 58 credits are taken from the major, and 21 to 25 credit hours are taken from minors such as Biology, Chemistry, Electronics, Physics, Mathematics, and Statistics. When majoring in Single-Track computer science, the student must also choose 3 courses ( 9 credit hours) as job enhancement courses. These courses have been designed to enhance the students understanding in certain fields that the job market needs. Currently, the following three tracks are available:

a) Business (management, marketing and accounting courses)

b) Electronics (electrical circuits I and II and electronics courses)

c) Information Systems (human computer interaction, the Internet concepts, and Java concepts).

\section{Sc. in Computer Science}

The Department will offer the M. Sc. program in computer science starting in September 1999. The Master's program prepares students for careers in which a higher level of education and experience is required. It provides advanced study in several areas of computer science including programming languages, computer architecture, artificial intelligence, operating systems, compilers, microelectronics, theoretical computer science, algorithms, database management, software engineering, parallel and distributed processing, networking, and scientific computation.

The student is required to successfully complete eight courses. This includes the three compulsory core courses, one required math course from the Department of Mathematics, three core courses from one of the tracks offered by the Science Department, one elective course from the Electrical Engineering Department or the Department of Business and Management. Compulsory courses include Operating Systems, Design \& Algorithms \& Data structures, and Software Engineering. Three courses are also taken from one of the available tracks such as Information Systems, Software Systems, Artificial Intelligence, Computer Systems and Theory of Computation.

\section{Cooperation with Local Businesses}

As a part of our efforts to update the curriculum, the Department decided to establish closer cooperation with lo- 


\section{Updating CS Curriculum}

cal business, especially with industry, by engaging more experienced faculty as consultants in planning, research, and development efforts that are critical to business (US Department of Commerce [USDC], 1994). This cooperation is built on mutual interests in sharing skills and knowledge between two different environments, academic and professional. In this cooperation, industry can benefit by obtaining the service of quality and relatively low-cost individuals (Peak \& O’Hara, 1998).

The program started gathering information on the current and future needs of several big companies and government ministries in Bahrain. This was followed by a series of discussions with representatives of local businesses where we presented and offered our expertise and skills in system planning and development. The program was guided by experienced faculty with the participation of students undertaking a project-based course in the final year of the degree.

After proving our abilities in conducting real projects, companies started assigning tasks to us, first simple and then more complicated ones based on their perceptions of our current experience and qualifications. After the success of earlier projects, we continued the cooperation with industry in a more professional manner, signing academic research contracts with companies and insisting on welldefined objectives, scope, and deadlines. Our first successfully completed project was designing and implementing of a decision support system using up-to-date IT technology and Geographical Information Systems (GIS) for the Fire and Safety Department of Bahrain Petroleum Company (Bapco). This system is an up-to-date risk management and emergency tool for the Incident Control Commander in the Refinery. It is used during simulated or actual emergencies, providing information to emergency management personnel based on accurate knowledge of equipment availability. After accepting the feasibility study, Bapco and the University of Bahrain signed a one-year research contract worth $\$ 27,000$.

The next projects included cooperation with mutual interests with Bahrain National Oil Company (Banoco), Bahrain Aluminum Extrusion Company (Balexco), Bahrain Telephone Company (Batelco), Bahrain Ministry of Housing, Municipalities and Environment, Survey Directorate and Municipalities, Bentley Systems, ESRI, Intergraph etc. In all these projects, special care was given to the concept of quality processes and a quality product (Hobbs, McGill, \& Rowe, 1998, Rout, 1992). The facul- ties were involved in developing methods of evaluation of the quality of developed applications. Students were encouraged to develop measures to assess the quality of developed applications and thoroughly test their software before the completion of their project.

There is no doubt that cooperation with industry and governmental agencies increases the market value and business experience of both students, and faculty that are involved in this cooperation in a real environment (Balakrishnan, Brown, Dunlap, \& Pahl, 1995). In this way students are exposed to a broad range of technologies and business environments. Furthermore, the Department is kept on top of product trends and new technology. The benefits of the cooperation for firms involved in the joint projects are temporary commitments and minimal cost of benefits (Peak \& O'Hara, 1998), providing an in-house training program for students that could become immediately productive employees joining the company.

The success of these projects created a positive attitude towards this type of cooperation elevated professional standing of all participants in this process, and improved rating of the Department within the College. Based on information collected from our R \& D, the Department could assess and adjust its programs benefiting both students and partners from industry.

\section{Conclusion}

The paper described an approach to update the curriculum of a typical computer science department through revising degree programs and involving faculty and students in active cooperation with local businesses, especially local industry. This approach maintains high educational standards while exploiting the potentials of the technology and, preparing students to become productive employees almost immediately after starting their careers. Furthermore, businesses that engage the students benefit by obtaining the services of quality, in-house trained, relatively low-cost individuals that can introduce new ideas into the organization. 
Mehic \& Al-Soufi

\section{References}

Balakrishnan, A., Brown, S., Dunlap, D., \& Pahl, R. (1995). Interdisciplinary industry-university collaboration: Lessons from an operations improvement project, Interfaces 25(5), 12-41.

Hobbs, V.J., McGill, T.J., \& Rowe, H.E. (1998). How good are students at assessing the quality of their applications, Informing Science Journal, 1(2), 23-28.

Mitchel, G.R., Carnes, K.H., \& Mendosa, C. (1994). America's new deficit: The shortage of Information Technology Workers, Reports, U.S. Department of Commerce, and Technology Administration.

Musthaler, L. (1997, October 13). IT. Prep: Are colleges delivering the goods?, LAN Times, http://www.lantimes.com (Sept. 1998).

O'Brien, P. S. (1998). Will you make the most of college and your carrier?, Microsoft Skills 2000: Growing Today's Workforce for Tomorrow's Technology, Articles, Microsoft. http://www.microsoft.com/skills2000/articles (Sept. 1998).

Peak, D. A. \& O'Hara, M. (1998). Practical liability of information technology education: Internship and consulting engagements, Informing Science Journal, 1(2), 43-51.

Pierce, K.R. (1994) Rethinking academia's conventional wisdom, IEEE Software, 10, 94-99.

Rout, T.P. (1992). The culture of quality and software engineering education, SIGCSE Bulletin 24(2), 29-34.
Schmidt, B. J., and Kirby, M.S. (1995). Technology and the development of critical thinking skills, In N. J. Groneman (Eds.), National Business Education Yearbook: No. 33. Technology in the classroom, 32-39.

Stanford Computer Industry Project Software. http://wwwscip.stanford.edu/scip. (Sept. 1998).

Tackett, R. (1998, February 16). Shape your career with new technology, LAN Times. http://www.lantimes.com (Sept. 1998).

Trendsetter Barometer, Coopers \& Lybrand, (July, 1996).

Triangle Coalition, Industry.s Role in the Reform of Mathematics, Science and Technology Education. the Triangle Coalition for Science and Technology Education. http://www.triangle-coalition.org./ (Oct. 1998).

US Cooperative State Research, Education, and Extension Service. (1997, August). National Awards Program for Excellence and University Teaching.

http://www.reeusda.gov/serd/hep/teaching.htm (Sept. 1998).

US Department of Commerce (USDC), National Science and Technology Council, (1994). Reports, Technology in the National Interest, Chapter. 2, A tradition of federal support for science and technology, government-industry partnerships for technology development, diffusion, and commercialization. http://www.ta.doc.gov/OTPolicy/reports.htm (Sept. 1998). 